\title{
FACILITATING CONSERVATION: PRIVATE CONSERVANCY LAW REFORM
}

\author{
ARLENE J. KWASNIAK*
}

Recognizing increasing pressure to protect wildlife areas and natural habitats, the author examines mechanisms available to private landowners who wish to set land aside for conservation purposes. Under existing law, it is very difficult to dispose of interests in land in ways assuring that conservation objectives will be fostered. The author surveys available common law and statutory mechanisms, arguing that none of these fulfils the objectives of private land conservancy. The common law of easements and restrictive covenants is not sufficiently changed by statute, leaving private landowners who wish conservation groups to care for their land with few altermatives. The author concludes by highlighting the benefits of law reform to facilitate such transfers. She proposes amendments to existing legislation which allow landowners to enter covenants with provincial ministers, municipal councils, and conservation groups. Such interests would be registrable at the Land Titles Office, and would run with the land without the need of a dominant tenement. These covenants would be enforceable by the organization with which the landowner entered the covenant, would be assignable, and would be able to exist in perpetuity.
Reconnaissant la pression croissante exercée en vue d'assurer la protection de la faune et de la flore sauvages et des habitats naturels, l'auteure examine les mécanismes statutaires auxquels peuvent avoir recours les propriétaires fonciers qui souhaitent réserver des terres à celte fin. Au terme de la loi existante, il est très difficile de disposer des intérêts fonciers de façon à assurer le respect des objectifs de conservation. L'auteure étudie les mécanismes de la common law et les dispositions législatives actuels et conclut qu'aucun ne satisfait les objectifs de protection des terres privées. La common law des servitudes et des restrictions n'est pas suffisamment modifiée par les statuts, laissant peu de choix aux propriétaires privés qui souhaiteraient confier leurs terres aux groupes de conservation. En conclusion. l'auteure souligne les avantages d'une réforme du droit qui faciliterait de tels transferts. Elle propose d'apporter à la législation actuelle des modifications qui permettraient aux propriétaires de conclure des ententes avec les ministères des provinces, les conseils municipaux et les groupes de protection de la nature. Ces engagements seraient enregistrables au bureau d'enregistrement garanti des droits immobiliers et seraient rattachés au bien-fonds sans qu'il y ait nécessairement de fonds dominant. L'organisme avec lequel le propriétaire se serait entendu serait tenu de faire respecter ces servitudes, qui seraient cessibles et susceptibles d'exister à perpétuité.

\section{TABLE OF CONTENTS}

I. INTRODUCTION ...................... 608

II. THE TYPICAL OBJECTIVES OF PRIVATE CONSERVANCY . . . . . . . . . . . . . . . . 610
A. OBJECTIVE (1): DISPOSING OF A PARTIAL
INTEREST FOR CONSERVATION PURPOSES $\ldots \ldots \ldots 610$
B. OBJECTIVE (2): TRANSFER TO A SUITABLE
CONTINUING ENTITY . . . . . . . . . . . 611
C. OBJECTIVE (3): BINDING PROTECTION IN

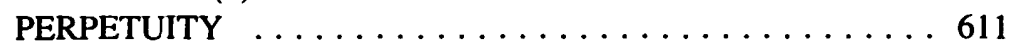



B.Sc., M.A., LL.B., LL.M. in Environmental and Natural Resources Law, and staff counsel with the Environmental Law Centre, Edmonton. I am grateful to Jennifer Shaw, the Environmental Law Centre's 1991 summer student, for her excellent research on private conservancy. 


\section{AN OVERVIEW OF LEGAL MECHANISMS}

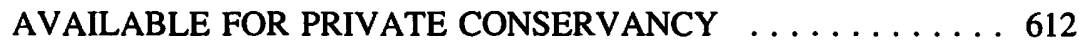

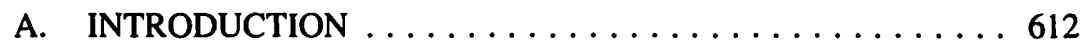

B. COMMON LAW EASEMENTS AND

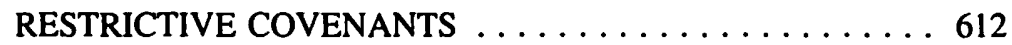

C. PRIVATE CONSERVANCY OBJECTIVES

AND COMMON LAW EASEMENTS AND

RESTRICTIVE COVENANTS . . . . . . . . . . . . 613

D. PRIVATE CONSERVANCY AND COMMON LAW

EASEMENTS AND RESTRICTIVE COVENANTS . . . . . 614

E. PRIVATE CONSERVANCY AND

STATUTORY LAW ..................615

F. SUMMARY OF COMMON AND

STATUTE LAW ...................... 619

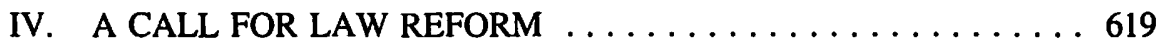

A. THE BENEFITS OF LAW REFORM .......... 619

B. THE EASE OF LAW REFORM ............. 621

APPENDIX: SUGGESTED PRIVATE CONSERVANCY

AMENDMENT TO EXISTING LEGISLATION .........6 622

\section{INTRODUCTION}

During the last decade, private individuals, non-governmental organizations and government agencies all have recognized that certain areas of land, because of special natural attributes or value as critical wildlife habitat, should be protected from development and other exploitation, and preserved in their natural state in perpetuity. The World Wildlife Fund Canada (WWF Canada) has set as a goal for the year 2000 that $12 \%$ of each province's land, whether publicly or privately owned, be set aside for conservation purposes, and has been vigorously pursuing this goal throughout Canada. ${ }^{1}$ The WWF Canada's goal mirrors, for this country, the worldwide goal recommended by the Brundtland Commission in Our Common Future. ${ }^{2}$ Public pressure and political movement are advancing legislative protection of wild areas and endangered or threatened species' habitat. ${ }^{3}$ Governmental and non-governmental groups have joined forces in programs aimed at protecting and preserving wildlife habitat. ${ }^{4}$ As well, significant sectors of the

See Endangered Spaces: The Future for Canada Wilderness (1990), WWF Canada, and Program Report, 1991, number 2.

2 Our Common Future, The World Commission on Environment and Development (1987), Oxford University Press.

3 For example, in Alberta there is currently public pressure on the Government to participate in the Canadian Heritage River System and the WWF $12 \%$ by 2000 program. The Alberta government has recently indicated its willingness to participate in these programs but has not yet formally committed itself.

4 An example is The North American Waterfowl Management Plan (1986) agreed to by Environment Canada, the Department of the Interior, the Fish and Wildlife Service and the United States Department of the Interior. The goal of the plan is to restore waterfowl populations to the 1970's level, primarily through protection and restoration of waterfowl habitat. The plan encourages cooperation between federal, provincial and state governments as well as private conservation groups, 
public constantly pressure governments to refrain from permitting developments which it believes will unduly harm natural environments and wildlife. ${ }^{5}$ Although motives and preferences differ regarding what should be preserved, the demand for preservation comes from all political sectors of society, from the extreme left to the extreme right.

Alberta's landscapes contain significant environmental diversity and wildlife habitat, much of which could be candidate for protection and reservation in its natural state in perpetuity. In fact, studies commissioned by Alberta government and private groups have targeted many specific areas of Alberta for preservation. ${ }^{6}$ Some of this land is Crown land and can be set aside and protected under current legislation. ${ }^{7}$ In view of this legislation, if candidate Crown land has not been set aside it is for lack of political will and not for lack of laws or mechanisms to facilitate preservation. ${ }^{8}$ However, much candidate land is privately owned, and accordingly, current conservation legislation is inapplicable. With private land, in contrast to public land, a major reason why more land has not been set aside is the absence of mechanisms including laws which can be utilized to facilitate preservation. With the private landowner the problem appears not to be lack of will. ${ }^{9}$

This article explains why current Alberta common law and legislation often fails to accommodate the landowner who wants to engage in private conservancy. Section II identifies three typical objectives of landowners who engage in private conservancy. Section III shows how existing legal mechanisms often prove to be impediments to meeting these objectives. Section IV urges law reform to eliminate the impediments and to facilitate landowners' wishes to set aside land for conservancy purposes. The section

such as Ducks Unlimited.

Examples of such public pressure abound. To cite just a few examples, consider the Great Whale Project, the Rafferty-Alemeda dam project, and closer to home, the various pulp mill and forest disposition projects and the Oldman River Dam project.

Studies commissioned by government include: Environmentally Significant Areas in the Oldman River Region Municipal District of Cardston, a study for Resource Evaluation and Planning, Alberta Forestry, Lands and Wildlife and the Oldman River Regional Planning Commission, Lethbridge, Alberta in 1987, and Environmentally Sensitive Areas Study; County of Strathcona and the D.S. of Sturgeon, prepared for Edmonton Metropolitan Regional Planning Commission, Edmonton in 1990; and Special Places 2000 see infra note 8. Private group studies include: Beaver Hill Moraine: An Analysis, a Comment and a Proposal, ELM \& Associates, 1988. Most significant of such Alberta Legislation is the Wilderness Areas, Ecological Reserves and Natural Areas Act, R.S.A., 1980, c. W-8.

The Alberta government has recently presented a draft proposal, which, if formally adopted (presumably by Cabinet) will demonstrate significant political will to preserve areas of public lands. The government released for public review a draft discussion paper entitled Special Places 2000: Alberta's Natural Heritage (Nov. 20, 1992). The paper is intended to be a "foundation document" which, if adopted by government, will commit it to legislatively protect a network of areas representing environmental diversity of the province. The paper is available from the Government of Alberta, Department of Environmental Protection.

For years the Environmental Law Centre has received requests to assist property owners, government agencies and non-governmental agencies in projects involving restricting development or use of private land in perpetuity for conservation purposes. In these cases, the Centre invariably has found the private landowner to be eager to carry out the project, but discouraged by the lack of mechanisms available to do so. 
suggests that the Alberta government would benefit from enabling such private voluntarism. In conclusion, the paper suggests amendments to existing legislation which would facilitate carrying out private conservancy.

\section{THE TYPICAL OBJECTIVES OF PRIVATE CONSERVANCY}

\section{A. OBJECTIVE (1): DISPOSING OF A PARTIAL INTEREST FOR CONSERVATION PURPOSES}

There are a number of ways for a landowner to dispose of an interest in land for private conservancy purposes. The simplest is where the landowner sells or donates an interest without obtaining prior subdivision approval. Such interest consists of either an entire parcel of land, for which a title exists at the appropriate Land Titles Office, or a parcel that can be carved out of a larger parcel without first obtaining subdivision approval. ${ }^{10}$ In this simple case, the landowner needs only to find an appropriate conservation group and to sell or donate the land to it." In the course of the transaction, the group will undertake conservation obligations relating to the parcel.

Unfortunately, this simple case is not the usual case. Even if conservation groups could always afford to acquire entire interests, (which they cannot) usually a landowner only wishes to dispose of a partial interest in land for conservation purposes. For example, a landowner might want only to protect waterfowl nesting ground in a wetland area of his or her property from any adverse development, but not preclude development on the entire parcel of land. To be divested of a partial interest, the landowner must either subdivide the land, or else find some other way to meet private conservancy objectives short of subdivision. If the landowner subdivides the land, it is possible to transfer the portion desired to be preserved to an appropriate conservancy group or else restrict development on the portion subdivided off for conservation purposes. ${ }^{12}$ However, more often than not, subdivision is not a satisfactory alternative. Subdivision approval may not be given readily, or alternatively, may be conditional on a dedication of a part of the land, as determined by the relevant planning authority. ${ }^{13}$ Sometimes a landowner simply wants to dedicate portions of private land for conservancy purposes and not dedicate an additional amount. Even more typically, landowners view the administrative hurdles posed

The Alberta Planning Act (R.S.A. 1980, c. P-9, s. 86) with only certain narrow exceptions, prohibits the registrar of the Land Titles Office from accepting for registration any transfer of land interest which has the effect of subdividing a parcel of land, unless subdivision approval has first been given under the Planning Act. Exceptions include: a landowner may, without prior subdivision approval, transfer a quarter section out of a larger parcel, transfer certain river lots or settlements referred to in s. 32 of the Surveys Act, (R.S.A. 1980, c. S-29), or transfer a part of a parcel described in the existing title if the boundaries of the part are described in the title.

"Several private and government, or government affiliated conservation groups act within Alberta, for example: ConservACTION, the Nature Conservancy of Canada, Nature Trust Alberta, Ducks Unlimited, the Alberta Department of Environmental Protection (formerly Forestry, Lands and Wildlife) Natural Areas Program, the Recreation, Parks and Wildlife Foundation Parks Venture Program, and the federal Government's Fish and Wildlife Habitat Program.

13 See the Alberta Planning Act, supra note 10, ss. 95, 96 and 98. 
by the subdivision process as unwanted impositions and transactional costs which outweigh their desire to part with an interest in land for conservation purposes. ${ }^{14}$ Landowners who engage in private conservancy most often would prefer to dispose of a partial interest in land without being burdened by having to obtain prior subdivision approval.

\section{B. OBJECTIVE (2): TRANSFER TO A SUITABLE CONTINUING ENTITY}

As well, the landowner wants to be assured that conservation obligations will be respected and enforced after the interest in the land has passed onto someone else. To this end, the landowner wants as much assurance as is possible that some continuing entity, like government, or a registered society, will act as watchdog to ensure that subsequent owners will respect conservation obligations, and failing such respect, will take enforcement action. A landowner's choice of continuing entity will be dependant on personal private conservation objectives. For example, a landowner wishing to preserve land as farmland might prefer an agricultural society to monitor compliance; a landowner who dedicates land for wildlife habitat protection might favour an organization like Nature Trust Alberta, Nature Conservancy, or ConservACTION; a landowner wishing to preserve waterfowl habitat might opt for Ducks Unlimited; or a landowner might prefer to transfer an interest to the government on the agreement that the government protect the interest for conservancy purposes. The point is, the landowner needs a suitable continuing entity of choice to aid in fulfilling private conservancy objectives.

\section{OBJECTIVE (3): BINDING PROTECTION IN PERPETUITY}

In addition, landowners who engage in private conservancy want to be assured that by giving up interests in land, the interests will be protected in perpetuity for conservation purposes. In the usual case, it would do little good for long term conservancy if, for example, only the landowner who gave up an interest could not develop it. The landowner wants to make sure that after he or she dies, or has otherwise conveyed the interest in land, the conservation obligations bind subsequent owners. The landowner wants, in legal terms, the conservation obligations to run with the land, regardless of who owns the land. In addition, the landowner wants to be sure that subsequent owners cannot simply discharge or release restrictions connected with the conservation obligations running with the land. Similarly, the landowner hopes that the restrictions will clearly bind at law so that a court cannot order them to be discharged on the basis that they were not initially perfected.

\section{SUMMARY}

A landowner engaging in private conservancy thus typically wants to accomplish three objectives. The landowner wants to: (1) dispose of a partial interest in private land for conservation purposes without having to obtain prior subdivision approval, (2) transfer the 
interest to a suitable entity and (3) be assured that conservation obligations will bind subsequent owners in perpetuity. The next section considers to what extent existing common law and statute law facilitate these objectives, and to what extent they impede them. ${ }^{\text {Is }}$ In so doing, the section demonstrates why private conservancy is so hard to effect.

\section{AN OVERVIEW OF LEGAL MECHANISMS AVAILABLE FOR PRIVATE CONSERVANCY}

\section{A. INTRODUCTION}

Both common and statutory law must be considered in determining what legal mechanisms are available for private conservancy. Common law principles will apply except in so far as they have been modified or derogated by legislative enactments. Legislation may confer rights or impede obligations not recognized at common law. This section analyses common and statute mechanisms available for private conservancy. The section concludes that neither adequately enables private landowners to meet the three objectives identified in section II of this article.

\section{B. COMMON LAW EASEMENTS AND RESTRICTIVE COVENANTS}

\section{Easements}

An easement generally gives the easement holder, the owner of one parcel of land (the grantee), a right to use the land of another (the grantor) for a specific purpose. Easements run with the land and bind subsequent owners in perpetuity. The common law requirements for an easement can be summarized as follows:

A. There must be a dominant tenement and a servient tenement. The dominant tenement is the parcel of land which benefits from the easement. The servient tenement is the parcel of land which is subject to the easement.

B. The easement must benefit the dominant tenement in the sense of making it a better or more convenient property.

C. The dominant and servient tenements must be separate parcels of land not owned and occupied by the same person.

There are, of course, other things that a landowner might want out of voluntarily giving up an interest in land for conservation purposes. For example, the landowner might want a charitable receipt, for federal income tax purposes, or a break on local authority property taxes. Although these issues are of utmost importance they are beyond the scope of this article. For a discussion of these issues see Conservation Kit: A Legal Guide to Private Conservancy, (1986) Environmental Law Centre, at 3034, 45-56, and 1988 tax update. In any event, a tax receipt from Revenue Canada, or a reduction of property taxes for diminished fair value are both dependent on the landowner actually disposing of an interest in land for conservation purposes, which is the focus of this article. 
D. Generally speaking, easements must be positive in character. An easement permits the owner of the dominant tenement to utilize the servient tenement for a purpose. For example, an easement might give the owner of the dominant tenement a right-of-way to pass over, put something on the servient tenement, or the right to discharge water onto the servient tenement. ${ }^{16}$

\section{Restrictive Covenants}

A restrictive covenant is an agreement between two landowners; one who promises not to use the land in a specific manner in order to benefit the land of the other. As with easements, the land burdened by the restrictive covenant is the servient tenement and the land which benefits from the restrictive covenant is the dominant tenement. Restrictive covenants, like easements, run with the land and bind subsequent owners in perpetuity. Conditions A, B and C above under Easements, also apply to restrictive covenants. However, in contrast to easements, restrictive covenants must be negative in character. Restrictive covenants prohibit the owner of the servient tenement from doing certain things on or with the land, in order to benefit the dominant tenement. A restrictive covenant could prohibit developing land in a certain manner; for example, it could prohibit building on the servient tenement above a certain height to ensure sunlight passage onto the dominant tenement.

\section{PRIVATE CONSERVANCY OBJECTIVES AND COMMON LAW EASEMENTS AND RESTRICTIVE COVENANTS}

Suppose a landowner wishes to preserve and enhance in perpetuity certain waterfowl habitat on private property. The waterfowl habitat area cannot be separated from title without subdivision approval and the landowner does not wish to apply for such approval. In these circumstances the landowner might consider common law easements and restrictive covenants. If the landowner can place legally valid restrictive covenants and easements on the property, he or she will have satisfied some of the objectives of private conservancy identified in Section II. Restrictive covenants could be used to prohibit drainage or interference with a natural wetland and easements, for example, to convey an access right to the lands, to enhance the wetland waterfowl easements run with the land and bind subsequent owners of the servient tenement in perpetuity, the landowner can be relatively assured that conservation objectives will continue to be met after death or transfer. Unfortunately, however, restrictive covenants and easements are not a panacea, and there are several stumbling blocks to the effective use of these servitudes as conservation tools. These shortcomings are briefly discussed below.

At common law there are a few categories of negative easements, whereby the owner of the servient tenement could be restricted from doing certain things with his property to benefit the dominant tenement. These negative easements restricted development on the servient tenement to enable light, air, support, or flow of water to benefit the dominant tenement. See S.G. Maurice, Gale on Easements, 15th ed. (London: Sweet \& Maxwell, 1986) at 38. It is moot whether new categories of negative easements are legally permissible. See McLean, "The Nature of an Easement" (1966) 5 Western Ont. L. Rev. 32. More than likely, any potential new class of negative easements would fall under restrictive covenants. 


\section{PRIVATE CONSERVANCY AND COMMON LAW EASEMENTS AND RESTRICTIVE COVENANTS}

\section{Objective (1) and the Requirement for a Dominant Tenement}

Objective (1), identified in section II of this article, of the landowner engaging in private conservancy is to transfer a partial interest in land for conservation purposes without having to obtain prior subdivision approval. One of the major stumbling blocks to meeting this objective with either easements or restrictive covenants is the requirement for a dominant tenement. Restrictions or easements placed on land which are not for the purpose of benefitting a dominant tenement are considered to be personal contracts only and neither run with the land nor are enforceable against subsequent owners. Hence, in order for a landowner to use these tools, there must be another parcel of land, i.e. a dominant tenement, which benefits from the restrictions or easements placed on the servient tenement. Moreover, at common law the other parcel, the dominant tenement, must be owned and occupied by someone other than the owner of the servient tenement. These common law conditions are rarely met. Landowners who want to operate an interest in land for private conservancy purposes typically act on their own. There simply is no benefitted separate parcel owned and occupied by someone in the wing to play the role of the dominant tenement owner. Even if there is, in the circumstances, the dominant tenement may not be benefitted from restrictions. Consequently, except in unusual cases, restrictive covenants or easements cannot be used to meet objective (1).

\section{Objective (2), Assignment Prohibition, and Ease of Discharge}

Objective (2) of the landowner is to transfer the interest to a suitable entity. One of the major stumbling blocks to meeting this objective is that under common law, only the owner of a dominant tenement has the right to enforce covenants contained in easements or restrictive covenants. That is, benefits of these covenants, including the right to enforce them, cannot be separated from the land and assigned to another party such as a conservation group. In order to enforce restrictive covenants or agreements, a person must have an interest in the dominant tenement. If a subsequent owner of the dominant tenement chooses not to enforce the restrictive covenants or easements, apparently no one can compel that person to do so. As well, since at common law the owner of the dominant tenement can release or discharge easements or restrictive covenants, a subsequent dominant tenement owner might do so, rather than having to bother with enforcing them. If such a subsequent owner could assign the benefit, instead of releasing or discharging obligations, the owner might simply transfer the enforcement right to a suitable, interested entity.

It should be noted at this juncture that the common law requirement for separate parcels of land to operate as the dominant and servient tenements does not apply to easements in the United States. United States law recognizes what are called "easements in gross." Easements in gross do not require a dominant tenement, and hence, can be placed on property by the owner of the servient tenement. As well, the benefit of an easement in gross can be assigned without a land transfer. The conservation organization Nature Trust uses easements in gross in the United States to readily effect private 
conservancy objectives. The method Nature Trust uses is: a landowner places "conservation easements" (actually restrictive covenants and easements) on private property, and assigns the right to enforce them to Nature Trust. Nature Trust, a continuing entity, then takes on and carries out the enforcement obligation. ${ }^{17}$

This "in gross" feature of easements makes private conservation objectives easier to attain in the United States than in Canada. Easements in gross are generally not part of the common law in Canada and hence, in all likelihood, absent statutory modification of the common law, a dominant tenement is necessary, and the benefit is not assignable without a transfer of the dominant tenement.

\section{Objective (3) and Elusive Common Law Conditions}

Objective (3) of the landowner is that conservation obligations bind subsequent owners in perpetuity. A potential stumbling block to meeting this objective concerns a lack of case law on conservation servitudes. Since restrictive covenants and easements have not traditionally been used for conservation purposes, a landowner cannot be assured by any body of law that these servitudes would hold up under judicial challenge. In particular, it is not clear to what extent wildlife habitat protection on servient land can be said to benefit a dominant tenement. For example, although at common law the dominant tenement and the servient tenement need not be contiguous, no one knows how far apart they can be to maintain a benefit. It is debateable, to say the least, for example, whether a wetland in central Alberta could operate as a servient tenement so as to benefit complimentary wildlife habitat in northern Alberta.

\section{E. PRIVATE CONSERVANCY AND STATUTORY LAW}

\section{Introduction}

Three Alberta Statutes are relevant to the use of restrictive covenants and easements for private conservancy. These are: the Land Titles Act, ${ }^{18}$ the Historical Resources Act ${ }^{19}$ and the Environmental Protection and Enhancement Act. ${ }^{20}$ As will be seen, although some of these statues partially remove common law impediments to meeting private conservancy objectives, they overall fail to adequately facilitate private conservancy.

I have found a number of people assume that this American method of effecting private conservancy can be used in Alberta. I suspect they base their assumption on American articles, pamphlets and books on private conservancy which are intended for a U.S., and not a Canadian audience. However, Canadians should be on alert even where the American material is intended for a Canadian audience. Last year I spoke at a Regional Trails Workshop (held by the Edmonton Metropolitan Regional Planning Commission, April 21, 1992, Edmonton) at which the invited speaker from the United States obviously assumed we in Canada could use the Nature Trust method. He wondered why we just didn't "get on with it."

Historical Resources Act, R.S.A. 1980, c. H-8. proclaimed in force September 1, 1993, except ss. 1(q), 151, 163-168, 225(a), (b) and 246(2), (3), (8) which are effective June 26, 1992. 


\section{The Land Titles Act}

S. 52 of the Land Titles Act (LTA) specifically recognizes restrictive covenants and s. 70 specifically recognizes easements. Registration under the LTA makes neither restrictive covenants nor easements run with the land. To run with the land, restrictive covenants or easements must be valid at common law, except where common law is altered by statute. Hence, except where altered by statute, to run with the land, restrictive covenants and easements must have a dominant and servient tenement, and be owned and occupied by separate persons, the servient tenement must benefit the dominant tenement and the benefit of restrictive covenants and easements are not assignable.

The LTA has modified common law regarding restrictive covenants and easements in at least three ways. First, s. 71 enables a landowner to grant himself an easement or restrictive covenant for the benefit of land which he owns against other land he owns. This section modifies the common law rule which requires that separate persons own the dominant and servient tenements. The section is not clear as to whether the dominant and servient tenements must be separate parcels of land, or could be a single parcel of land, although the Alberta Attorney General Land Titles Procedures Manual assumes that two registered parcels are required. ${ }^{21}$

Second, the LTA may have an indirect effect on these servitudes' running with the land at common law. Under the LTA, absent fraud, the purchaser of the property takes title free and clear of all unregistered interests. ${ }^{22}$ If the holder of a valid restrictive covenant or easement registers the interest under the Act, it runs with the land and binds subsequent purchasers of the servient tenement. However, if the holder fails to duly register the interest, a subsequent purchaser probably takes title free of it and the interest will probably cease to run with the land.

Third, until 1985 , easements or restrictive covenants could only be discharged or modified by the court. ${ }^{23}$ However, since 1985, the registrar is required to cancel the registration of easements or restrictive covenants when discharged by the registered owner of the dominant tenement. ${ }^{24}$ This 1985 amendment made the LTA more consistent with the common law, since at common law, the owner of the dominant tenement may release or discharge a restrictive covenant or easement. However, this provision does little for private conservancy objectives when an owner of the dominant tenement places restrictive covenants or easements on his own land under s. 71 . Once the owner of the dominant tenement transfers the land, the subsequent owner is free to discharge the conditions or covenants. Note that this would not be a problem if the owner could assign the benefit of easements or restrictive covenants to a conservation organization. 


\section{LTA Summary}

Although the LTA preserves common law restrictive covenants and easements, it does very little to facilitate private conservancy by removing common law stumbling blocks. The LTA preserves the need for both a dominant and a servient tenement, the rule against assigning the benefits of restrictive covenants or easements, and the uncertainty over the existence of a benefit to the dominant tenement. Although the LTA does modify the common law by enabling the same owner to own both the dominant and the servient tenement, since the owner of the dominant tenement cannot assign the right to enforce restrictive covenants or easements, any subsequent owner of the dominant tenement may simply discharge and release the burdens.

\section{The Historical Resources Act}

Although the Historical Resources Act (HRA) is geared primarily to the protection of historic, archaeological and paleontological sites, in theory it could be used to protect valuable natural areas. This is because the $s .25$ of the HRA broadly defines "historic resource" to mean:

any work of nature or of man that is primarily of value for its paleontological, archaeological, prehistoric, historic, cultural, natural, scientific, or aesthetic interest, to, including but not limited to a paleontological archaeological, prehistoric, historic, or natural site, structure, or object. (emphases added)

Given the scope of this definition, whether intended or not by legislators, a range of natural sites candidates for private conservancy fit under the definition of a historic resource.

The HRA goes much farther than the LTA in modifying common law regarding restrictive covenants or easements, to make it easier for private individuals to protect historic resources in perpetuity. S. 25 enables an owner to enter into an agreement with the Minister administering the Act, ${ }^{25}$ the Council of the Municipality in which the land is located, the Alberta Historical Resources Foundation, or an historical organization approved by the Minister, which agreement may be registered at the appropriate Land Titles office. The conditions or covenants run with the land and may be enforced whether they are positive or negative in nature and notwithstanding that the person or organization that entered into the condition or covenant with the owner does not have an interest in any land that would be accommodated or benefitted by the condition or covenant. The conditions or covenants are assignable by the person who or organization which entered into the agreement with the owner to any other similar person or organization, and then the assignee may enforce the conditions or covenants. The Minister may order a discharge or modification of a covenant or condition if the Minister considers it to be in the public interest, whether or not a party to the agreement. of Culture and Multiculturalism. The HRA is now administered by the Minister of Community Development. 
Most of these HRA provisions constitute major improvements over the common law. Most importantly, the HRA meets objective (1) by doing away with the requirement for a dominant tenement. The Act, in effect, authorizes restrictive covenants or easements in gross. As well, the HRA modifies the common law by stating that conditions or covenants need not be positive or negative. This facilitates objective (3) by removing the concern. over the uncertainty of the common law, and should detract court challenges over the validity of such covenants.

Notwithstanding its positive features, there are problems with the HRA which make it unlikely to be a useful tool in private conservancy. First, although in theory the Act could apply to natural areas, its focus and emphasis are on historic, archaeological and paleontological resources. It is unlikely that the Minister would see her mandate as extending to private conservancy projects not involving these resources. Second, the list of persons or organizations with which or whom an owner can enter into a restrictive covenant or easement agreement with, is too limited to meet objective (2). Given landowners varied interests, they need the opportunity to enter into a private conservancy agreement with any one of a range of organizations, including private conservation groups. The HRA does not allow this. Third, under the HRA, the Minister may discharge or modify a condition or covenant. This statutory power, especially that of being able to "modify" covenants or agreements, could deter the use of the HRA to put private conservancy projects into effect. The provision gives the Minister an undefined power over private land that landowners justifiably might find unacceptable. It would be preferable that agreements be modified only by the court, or at the direction of both the party which benefits from the agreement and the owner of the servient tenement.

\section{The Environmental Protection and Enhancement Act}

Once law, the Alberta Environmental Protection and Enhancement Act (EPEA) ${ }^{26}$ will replace and consolidate eight environmental statutes including the Land Surface Conservation and Reclamation Act. ${ }^{27}$ The Land Surface Conservation and Reclamation Act contains provisions under which a landowner can enter into an agreement with the Minister for the purposes of conservation. A modified version of these provisions have been carried through to EPEA. S. 20 of EPEA enables the Minister ${ }^{28}$ to enter into an agreement with the registered owner of the land to restrict the purposes for which that land may be used, in order to protect and enhance the environment. The section states that the agreement may be registered under the LTA, runs with the land, and is enforceable whether it is positive or negative in nature, notwithstanding that the government has no interest in any land that would be accommodated or benefitted by the agreement. The section does not state who has the right to enforce the agreement, nor does it indicate who can discharge the agreement prior to the end of its term. supra.

27 Land Surface Conservation and Reclamation Act, R.S.A. 1980, c. L-3.

28 S. $1(\mathrm{~mm})$ of EPEA states that "Minister" means the Minister of the Environment. The government recently collapsed this department. Once enacted, administration of EPEA will presumably be transferred to the newly formed Department of Environmental Protection. 
Although most of these EPEA provisions, like similar provisions in the HRA, constitute major improvements over the common law, they fall short of adequately facilitating the objectives of private conservancy. First, since EPEA assumes that conservation agreements will terminate, it could be inconsistent with objective (1) that a partial interest actually be transferred, and with objective (3) that the interest be protected in perpetuity. Second, EPEA fails to meet objective (2) since owners wish to enter into agreements with a conservation group of their choice and not necessarily with the Minister under the Act. As well, since the EPEA does not mention whether any benefits from the covenants or other agreements can be assigned, it is arguable that the common law prohibition against assignment applies. ${ }^{29}$ Third, it may fail to meet objective (3) on account of ambiguity which might ultimately affect the validity of covenants and easements. For example, s. 22(1) authorizes the Minister to enter into an agreement to "restrict the purposes for which land may be used," although s. 21(4) states that the agreement may be positive or negative in nature (emphases added). Hence, although s. 21(1) appears to authorize the Minister to only enter into a restrictive covenant agreement, s. 21(4), with no account given, contemplates that the agreement can cover a broader range of interests. Finally, because it is unclear who may enforce a conservation agreement, there is no guarantee that it will be enforced.

\section{F. SUMMARY OF COMMON AND STATUTE LAW}

In summary, Alberta common law imposes several obstacles to carrying out private conservancy objectives. These obstacles are: the requirement for a dominant and servient tenement owned by separate persons, the fact that the benefit of restrictive covenants and easements are not assignable short of a land transfer, and the indeterminateness of the common law regarding what conservation obligation can be the object of restrictive covenants and easements. Although Alberta statute law has improved on the common law, it falls short of sufficiently facilitating the objectives of private conservancy. Although the relevant sections of the LTA, HRA and EPEA take landowners part of the way towards realizing their private conservancy objectives, the same pieces of legislation frustrate these objectives, and, in most cases, leave landowners only with the difficult common law rules to finagle to accomplish their aims.

\section{A CALL FOR LAW REFORM}

\section{A. THE BENEFITS OF LAW REFORM}

The fact that the Alberta government has partially removed barriers to engaging in private conservancy indicates its willingness to accommodate these ends. Hopefully the government will complete its accommodation by passing legislation which more easily

29 It is also arguable that since EPEA recognizes in gross interests that the right to assign follows. Nevertheless, the issue is not clear. It would be preferable for the statute to specifically recognize at least a limited right of assignment to specified entities, including appropriate conservation groups. 
facilitates the goals of private conservancy than what is currently available. ${ }^{30}$ The Alberta government could benefit from passing such legislation for many reasons. Among those reasons are first, governmental agencies, primarily Alberta agencies, which are currently engaged in private conservancy projects could use private conservancy legislation to facilitate their objectives. For example, the successor departments to Alberta Forestry Lands and Wildlife and Alberta Agriculture would be facilitated in their current attempts to achieve a province-wide expansion of the Landowner Habitat program. ${ }^{31}$ As well, the partners in ConservACTION, a program which enlists landowners who wish to retain wildlife habitat on private property, would benefit. These partners are: Environment Canada, Environmental Partners Fund, Alberta Fish and Wildlife Division, Strathcona County Parks and Culture, and Sherwood Park Fish and Game Association. ${ }^{32}$ Also, it would assist in the carrying out of the Public Lands Division, Natural and Protected Areas programs, and Recreation, Parks and Wildlife Foundation in the carrying out of its Parks Ventures Fund program. Second, it would benefit a range of special interest groups including Ducks Unlimited, Nature Trust Alberta and Nature Conservancy, by assisting them in carrying out private conservancy projects that similar organizations can more easily carry out in other jurisdictions. Third, it would benefit a diverse range of Albertans interested in private conservancy but frustrated by administrative hassles and complex and burdensome common and statutory law. ${ }^{33}$ Fourth, it would improve Alberta's record in setting aside lands for conservation purposes. As mentioned in the Introduction, the WWF Canada's goal for each province setting aside for conservation purposes $12 \%$ of its lands can be satisfied out of either public or private lands. By facilitating private conservancy through legislative reform the Province's record would improve with each private conservancy project. Fifth, by facilitating private conservancy the government would further the objectives set forth in its draft Special Places 2000 project. ${ }^{34}$ This draft policy, if put into effect, will set into motion a process to protect all representative ecosystems in the Province. Unfortunately, not all of these ecosystems are prevalent on public land. By facilitating private conservancy though law reform, the Special Places 2000 project could more fully and efficiently endeavour to meet its objectives. Sixth, enhancing conservation opportunities through law reform would advance the worldwide goals of sustaining resources in global attempts to achieve environmentally sound sustainable development. These goals are reflected internationally in the Brundtland Report mentioned in the introduction of this article ${ }^{35}$ and in United Nation Conference

I have recently spoken with a representative from the Department of Environmental Protection who stated that the Government in the next few months will seriously consider legislative reform to facilitate private conservancy. She also said that the Environmental Law Centre will be consulted in this process. We, of course, find this to be very good news and look forward to participating. I assume that the recently formed departments of Environmental Protection and Agriculture and Rural Development have or will formally adopt the Landowner Habitat Program. I am unaware of any formal adoption.

32 I have worked extensively with ConservACTION, in assisting it to develop strategies and methods to use current common and statute law to fulfil landowners' conservancy objectives. It is mainly through this work that I came to realize how inadequately the current law is facilitating private landowners' admirable desires to voluntarily part with interests in land for the common good. The claims regarding how governmental and non-governmental groups might benefit from law reform are based on discussions with representatives of these groups.

34 Government of Alberta, Special Places 2000; Alberta's Natural Heritage, Draft, supra note 8.

35 Supra note 2 and accompanying text. 
on Environment and Development (UNCED) commitments, ${ }^{36}$ nationally through the work of the National Round Table, and provincially, through the numerous provincial round tables on sustainable development including the Alberta Round Table. Seventh, and most important, preserving and maintaining the land, water, flora and fauna in Alberta will enhance the integrity of the complex ecosystems of Alberta, and consequently improve the Province itself, and consequently benefit present and future generations of Albertans.

\section{B. THE EASE OF LAW REFORM}

By undertaking legislative reform to facilitate private conservancy the Alberta Government would not be engaging in a novel enterprise. Prince Edward Island and Nova Scotia have enacted legislation to enable landowners to protect their land in perpetuity for conservation purposes. ${ }^{37}$ Other provinces, including British Columbia and Saskatchewan, are currently considering similar law reform. As well, in the United States, over 40 states have enacted conservation easement statutes, and only a few states completely lack legislation which authorizes restrictions on private land use. ${ }^{38}$

Legislative reform should not be too difficult to bring about. The Government of Alberta has at least two options in undertaking private conservancy legislation. It could introduce simple amendments to existing legislation, most logically the LTA or EPEA, or alternatively, introduce a new statute which deals only with private conservancy objectives. In either of these cases, to overcome current obstacles such legislation must account for the following:

1. It must enable a condition or covenant relating to the preservation of land or water to be entered into by the owner of land and the appropriate Minister, a municipal council where the land is located, or an appropriate conservation group.

2. The condition or covenant must be registerable at Land Titles.

3. The condition or covenant must be stated to run with the land, whether it is positive or negative in nature, and notwithstanding that the person or organization which entered into the condition or covenant does not have an interest in any land which may be accommodated or benefitted by the condition or covenant. (In other words, no dominant tenement should be necessary, and the common law rules regarding positive or negative covenants should be loosened).

4. The condition or covenant must be enforceable by the person or organization that entered into the condition or covenant with the owner.

UNCED commitments reflecting this goal include the Rio Declaration on Environment and Development, the Biodiversity Convention and numerous provisions in Agenda 21.

37 Natural Areas Protection Act, S.P.E.I. 1988, c. 46. and Conservation Easements Act, S.N.S. 1992, c. 2.

38 A. Dana and M. Ramsey, "Conservation Easements and the Common Law" (1988) 8 Stan. Env'l L.J. $2-45$. 
5. The benefit of the condition or covenant must be assignable to a person or organization meeting the same criteria as the original person or organization benefitting from the covenant or condition.

6. The condition or covenant must be able to exist in perpetuity.

Although at first blush meeting the requirements in these six paragraphs may seem to require extensive amendment to existing legislation or a whole new act, on reflection, it should require only relatively simple amendments to existing legislation, such as the LTA or EPEA. In conclusion, the appendix to this article suggests such amendments. ${ }^{39}$

\section{APPENDIX: SUGGESTED PRIVATE CONSERVANCY AMENDMENT TO EXISTING LEGISLATION}

1(1) A condition or covenant relating to the preservation of any land or water, including open spaces, entered into by the owner of land and

(a) the Minister,

(b) a Government agency which administers a private conservancy program,

(c) the Council of the Municipality in which the land is located,

(d) a society registered under the Alberta Societies Act, organized for private conservancy purposes, or

(e) any other person or organization other than the preceding which is approved by the Minister,

for a stated period, or in perpetuity, may be registered with the Registrar of Land Titles of the land registration district in which the land is located.

(2) When a condition or covenant under subsection (1) is presented for registration, the Registrar of Land Title of the Land Registration District in which the land is located shall endorse a memorandum of the condition or covenant on any certificate of title relating to that land.

(3) A condition or covenant registered under subsection (2) runs with the land and the person or organization under subsection (1) that entered into the condition or covenant with the owner may enforce it whether it is positive or negative in nature and notwithstanding that the person or organization does not have an interest in any land that may be accommodated or benefitted by the condition or covenant.

(4) A condition or covenant registered under subsection (2) may be assigned by the person or organization that entered into it with the owner to any other person or organization mentioned in subsection (1), and the assignee may enforce the condition 
or covenant as if it were the person or organization that entered into the condition or covenant with the person.

(5) The condition or covenant may be modified or discharged in the same manner as restrictive covenants or easements may be modified or discharged under the Land Titles $A c t$, and the Registrar of Land Titles for the land registration district in which the land is located shall accordingly endorse a memorandum discharging or modifying the condition or covenant on the certificate of title to the land.

(7) This section applies notwithstanding section 52 of the Land Titles Act.

(8) No condition or covenant under this section shall be deemed to be an encumbrance within the meaning of the Land Titles Act or the Tax Recovery Act.

(9) A covenant or condition under this section may be enforced by

(a) the Minister,

(b) the person, agency or group under s. 1(1) who entered into the condition or covenant with the owner or alternatively, the assignee under s. 1(4) of such person, agency or group, or

(c) a person authorized by other law. ${ }^{40}$

(10) Any person entitled to enforce a covenant or condition under this section may bring an enforcement action. In addition to any other remedy available at law, the Court in its discretion, may grant legal or equitable remedies, including injunction, or both.

An earlier version of this paper provided that the owner of an interest in the real property burdened by the condition or covenant, should be able to enforce the covenant or condition. This provision is in some of the U.S legislation. I deleted the provision from this paper because of federal income tax requirements regarding gifts of property. For federal tax purposes, for a disposition to be considered a gift of property, generally, the transferor must have released the right to control the property to the transferee. The provision in the earlier version giving the transferor the right to enforce conservation obligations, might suggest that the transferor has retained a measure of control over the property. 